\title{
THE DEVELOPMENT STRATEGY OF INDONESIAN NAVAL HUMAN RESOURCES UNIT USING SWOT ANALYSIS AND INTERPRETATIVE STRUCTURAL MODELLING
}

\author{
Mukhlis, Cahyanto, Ikhwan Syahtaria, Adi Bandono \\ Indonesian Naval Technology College, STTAL, Surabaya, Indonesia \\ e-mail:cahyaafkar@gmail.com
}

\begin{abstract}
Lapetal is an organization within the Indonesian Navy that is tasked with carrying out Navy recruitment. With the increasing number of duties and responsibilities of Lapetal and seeing the current condition of Lapetal, it is necessary to make efforts to develop Lapetal in the future. The purpose of this research is to identify the factors that influence in determining the Lapetal development strategy, determine the alternative strategy for Lapetal development, and produce a roadmap of the selected alternative strategies for Lapetal development. This study uses an integrated SWOT analysis and Interpretative Structural Modeling. SWOT analysis is used to formulate and provide alternatives in Lapetal development strategies. ISM is used to determine the priority order of the selected strategy which is then applied in making the roadmap. Based on the results of the SWOT matrix analysis, the SO Strategy consists of 6 (six) strategic steps, the ST Strategy consists of 5 (five) strategic steps, the WO Strategy consists of 8 (eight) strategic steps and the WT strategy consists of 4 (four) strategic steps. Based on weighting using the EFAS and IFAS matrices, the chosen strategy is the WO Strategy, so that the WO strategy becomes the first alternative. Based on the results of the classification of elements in the WO strategy, there are 4 (four) levels of hierarchical structure. In this hierarchical structure, it can be seen that the (WO5) and (WO6) sub-strategies are at level IV. Then the sub strategies (WO3) and (WO4) are at level III. At level II it consists of 3 (three) sub strategies, namely (WO1), (WO2), and (WO7). At level I, it is the sub strategy (WO8). The output of the SWOT and ISM analysis process in determining the Lapetal development strategy is a map or roadmap implemented in a strategic plan which is divided into five-year programs.
\end{abstract}

Keywords: Lapetal, Development Strategy, SWOT, ISM, Road map.

\section{INTRUDUCTION}

The task of the Indonesian Navy is to carry out the duties of the TNI in the marine sector in the field of defense and to carry out the duties of the Indonesian Armed Forces (TNI) in the development of forces, especially the marine dimension. In line with this task, the Indonesian Navy plans the development of the Indonesian Navy Posture which includes the level of capability, strength and pattern of force titles, which are essentially oriented towards the achievement of Indonesian Navy tasks in support of national interests (Kemenhan, 2004). Determination of the development of the Indonesian Navy's strength towards the Minimum Essential Force (MEF) in 2024 (Mabesal, 2019), is a reference or road map used in the development of the Indonesian Navy's posture going forward.

To achieve this, the Indonesian Navy organization requires qualified and reliable human resources to monitor it. The provision of quality human resources in the Indonesian Navy requires a qualified recruitment organization, in this case the Indonesian Naval Human Resources Unit (Lapetal).
Lapetal is an organization under the Navy Personnel Administration Service (Disminpersal) which is tasked with carrying out various things related to the recruitment of Indonesian Navy soldiers. Based on the TNI Commander's Regulation Number 6 of 2016 concerning the recruitment of voluntary TNI Soldiers, it is stated that the supply function includes several stages (Mabesal, 2013), including:
a. Campaign
b. Recruitment.
c. First education.
d. Appointment.
e. First Service Ties (IDP)

In supporting the implementation of its main duties, the Indonesian Navy always maintains the performance of the organization's performance to create an effective and efficient performance (Harky, 2018). This is a demand that must be considered in every organization, therefore the Indonesian Navy needs qualified and qualified Human Resources in terms of capability and professionalism.

Quality human resources who are within the Indonesian Navy have a very important role. Because with the availability of the Indonesian Naval Main 
Weapon System (Alutsista) which is increasingly numerous and sophisticated as well as the challenges in the era of the industrial revolution 4.0 (Mashudi, 2019), it is hoped that its human resources will be able to manning the defense equipment reliably. In looking for quality human resources, a good plan is needed to achieve optimal organizational goals in the utilization of existing resources.

The provision of quality human resources in the Indonesian Navy requires a qualified human resources organization, in this case, carried out by The Indonesian Naval Human Resources Unit (Lapetal). Faced with the expansion of the Indonesian Naval organization, namely the formation of a new unit/organization and also the addition of defense equipment, the duties, and responsibilities of the Lapetal will be heavier because it also causes the recruitment of Indonesian Naval personnel in the future. With the increasing number of duties and responsibilities of Lapetal and seeing the current condition of Lapetal, it is necessary to make efforts to develop Lapetal in the future.

Based on the current condition of Lapetal, the researcher will research Lapetal development strategies using a SWOT analysis. This study aims to obtain the factors and criteria that affect the Lapetal development strategy and to obtain the formulation of the Lapetal development strategy.

\section{MATERIALS/METHODOLOGY}

\subsection{Concept of Organizational Development}

\section{Strategy}

Etymologically it is a derivative of the Greek word strategos. Strategos can be translated as "military commander" in the democratic era of Athens. Meanwhile, in terms of terminology, many experts have put forward the definition of strategy with different points of view, but basically, all of them have the same meaning or meaning, namely achieving goals effectively and efficiently.

According to (Istiqomah, 2017) strategic management can be defined as the art and science of formulating, implementing, and evaluating crossfunctional decisions that enable an organization to achieve its goals. Historically, the main benefit of strategic management has been to help organizations formulate better strategies by using a more systematic, logical, and rational approach to strategy choice.

\subsection{The Indonesian Naval Human Resources Unit (Lapetal).}

The provision of quality human resources as crews of the Indonesian Armed Forces organization has a significant, strategic, and comprehensive influence on every activity of the organization and management to achieve the expected performance. In supporting the task of providing these soldiers at the Indonesian Navy, it is carried out by Lapetal which has an office at Jalan Yos Sudarso Malang, East Java and is headed by a Colonel Intermediate Officer. Lapetal is the front liner in the recruitment process for members of the Navy and has a strategic function in obtaining qualified human resources who meet qualifications and character standards.

Based on the TNI Commander Regulation Number 30 of 2014 concerning the Provision of Volunteer Soldiers for the Indonesian Armed Forces (Mabes TNI, 2014), what is meant by the provision are all activities carried out to process a citizen to become a Volunteer Soldier of the Indonesian Armed Forces by the specified requirements, which includes campaigns, admissions, first education, appointment, and first service ties.

\subsection{SWOT Analysis Concept}

SWOT analysis is the most common technique that can be used to analyze strategic cases (Hill \& Westbrook, 1997). SWOT is a tool that is often used to analyze the internal and external environment to achieve a systematic approach and support for decision situations (Wheelen \& Hunger, 2012). SWOT is an acronym for strength (S), weakness (W), opportunity $(\mathrm{O})$, and threat $(\mathrm{T})$. The first two factors (strengths and weaknesses) are related to internal organizational factors, while opportunities and threats cover the broader context or environment in which the entity operates (Collins-Kreiner \& Wall, 2007).

Internal and external factors are referred to as strategic factors and are summarized in the SWOT analysis. Strengths and weaknesses are factors in the system that allow and hinder the organization from achieving its goals. Opportunities and threats are considered as external factors that facilitate and limit the organization in achieving its respective goals (Wasike, et al., 2010).

In table 1, The SWOT analysis shows the appropriate strategy in the four categories SO, ST, WO, and WT. The strategy identified as SO involves taking advantage of opportunities using existing strengths. ST is a strategy related to using force to eliminate or reduce the effects of a threat. Likewise, the WO strategy seeks to take advantage of the opportunities presented by external environmental factors by taking into account its weaknesses. The fourth and final one is WT, where an organization tries to reduce the impact of its threats by considering its weaknesses (Yuksel \& Dagdeviren, 2007).

Furthermore, in this study, the SWOT analysis method is used to identify and formulate several strategies for developing the posture capability of the Indonesian Navy. The SWOT analysis method used in the development strategy is integrated with the MIDLIFE military strategy area corridor and the Naval strategy with the theoretical approaches of Alfred Thayer Mahan and Julian Stanford Corbett.

Table 1. SWOT Analysis Matrix

\begin{tabular}{|c|c|c|}
\hline $\begin{array}{c}\text { INTERNAL/EXTERNAL } \\
\text { FAKTOR }\end{array}$ & $\begin{array}{c}\text { STRENGTH(S) } \\
\text { (Maximal) }\end{array}$ & $\begin{array}{c}\text { WEAKNESS (W) } \\
\text { (Minimal) }\end{array}$ \\
\hline $\begin{array}{c}\text { OPPORTUNITES (O) } \\
\text { (maximal) }\end{array}$ & $\begin{array}{c}\text { S-O Strategy } \\
\text { (Maximal-Maximal) }\end{array}$ & $\begin{array}{c}\text { W-T Strategy } \\
\text { (Minimal-Minimal) }\end{array}$ \\
\hline $\begin{array}{c}\text { THREATS (T) } \\
\text { (Minimal) }\end{array}$ & $\begin{array}{c}\text { S-TStrategy } \\
\text { (Maximal-Minimal) }\end{array}$ & $\begin{array}{c}\text { W-O Strategy } \\
\text { (Minimal-Maximal) }\end{array}$ \\
\hline
\end{tabular}




\section{RESULT AND DISCUSSION}

\subsection{Collection of Technical Data}

In the early stages of data collection in the form of primary data and secondary data. Primary data is the process of taking data directly in the field by making observations to find out the facts or conditions. The initial stage in this data collection activity is carried out by interviewing the Chief of Lapetal and staff, to get an objective picture directly about the existing conditions as well as the fundamental factors that are part of the Lapetal. In addition to the above, a literature study was carried out through references from Indonesian Navy publications which were secondary data in this study. In addition to secondary data collection, primary data collection was also carried out by conducting interviews and distributing questionnaires to obtain data from respondents following their fields.

\subsection{Existing Lapetal Conditions}

The current condition of Lapetal as a human resources institution can only carry out 2 (two) stages of Provision, namely the campaign/socialization stage and the recruitment stage. Meanwhile, other stages have not been implemented (Lapetal, 2018)

This is because the organizational structure and number of personnel according to the Personnel Composition List (DSP) in the Organization and Procedures are not proportional, meaning that the main activities with the number of personnel are not appropriate so that they do not fully support the implementation of activities optimally. While the current DSP has not changed/added the number of personnel, therefore it is hoped that there will be a change in the organizational structure and an increase in the number of Lapetal personnel so that the Provision process activities can run according to their stages and optimally.

The organizational structure of Lapetal chaired by a Kalapetal with the rank of Colonel (grade 13) is a very strategic position because it is the stakeholder of Provision activities. Where the duties and responsibilities are very large. This is because the process of providing Indonesian Navy soldier candidates is only carried out by one institution which is headquartered in the city of Malang, East Java, while the process and outputs of their duties are for the Indonesian Navy organization.

Faced with the expansion of the Indonesian Navy organization, namely the formation of a new unit/organization and also the addition of defense equipment, the duties, and responsibilities of the Lapetal will be heavier because it also causes the recruitment of Indonesian Navy personnel in the future.

\subsection{Internal Factor Analysis}

Analysis of the internal environment aims to identify several strengths and weaknesses in the internal resources and processes that are owned. Internal activity resources and processes are said to have strength if these internal activity resources and processes have the capability that will create excellence in an organization. After the existing data is collected, which is obtained from documents, literature review, preliminary interviews with resource persons (Expert), the elements of internal factors are obtained as follows:

Table 2. Elements of Internal Factors

\begin{tabular}{|c|c|}
\hline MO & FACTOR \\
\hline 1 & $\begin{array}{l}\text { Lapetals are only able to carry out } 2 \text { stages of provision, namely socialcation and } \\
\text { acceptance. }\end{array}$ \\
\hline 2 & $\begin{array}{l}\text { There are no detaled work instruchions in carrying out the selection process for the } \\
\text { recrutment of indonesian Nawy soldiers, especialy the regional selection. }\end{array}$ \\
\hline 3 & There is no special section that handles socializationicampaigning. \\
\hline 4 & No division handles the security sector. \\
\hline 5 & In terms of quanfity and quality, fhe aumber of personnel is spll lacking. \\
\hline 6 & Lapetal personnel have very high mofivation/performance. \\
\hline 7 & $\begin{array}{l}\text { Training for recruiting Indonesian Navy soidiers to al Lapetal personnel and } \\
\text { representatives of all regional committees. }\end{array}$ \\
\hline 8 & The transportation and commurication system in Lapetal is quite good. \\
\hline 9 & $\begin{array}{l}\text { The avalability of equipment in the socialcation and selection activites is quite } \\
\text { adequate, however, it needs to be improved, especially documentation equipment. }\end{array}$ \\
\hline 10 & $\begin{array}{l}\text { The facities and infrastructure used for the implementation of the central selection stil } \\
\text { use those of the Malang Naval Base. }\end{array}$ \\
\hline
\end{tabular}

Based on the tabulation of the internal factors, the number of internal factor criteria is obtained, then the classification of the strengths and weaknesses factors. With the following formula:

Overall average score $=\frac{\text { The average number o feach factor }}{\text { Number of factors forintemal criteria }}$

(1)

Then we get the tabulation of internal factors as follows:

Table 3. Tabulation of Internal Factor Elements

\begin{tabular}{|c|c|c|c|c|}
\hline NO & FACTOR & TOTN & AVERAGE & CRTERES \\
\hline$T$ & 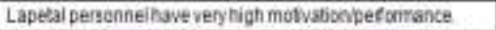 & 29 & 725 & 5 \\
\hline 2 & 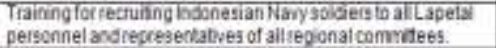 & 26 & $t$ & 5 \\
\hline 3 & $\begin{array}{l}\text { The transportatoo and communcabion systemn Lapetalis } \\
\text { gute good }\end{array}$ & 27 & 5.75 & $\$$ \\
\hline 4 & 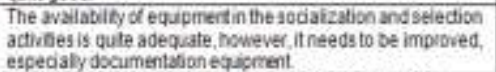 & 25 & 5.5 & 5 \\
\hline 6 & $\begin{array}{l}\text { Lapezals ale onty ableto caty out } 2 \text { sages d provition. } \\
\text { namely sooglession and recoultment. }\end{array}$ & 17 & 4.25 & $w$ \\
\hline है & 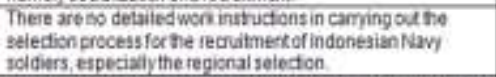 & 15 & 375 & $\mathrm{~W}$ \\
\hline 7 & 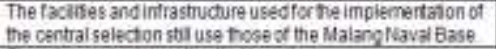 & 15 & 375 & $w$ \\
\hline 8 & 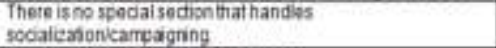 & 14 & 35 & $w$ \\
\hline 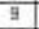 & No dwsion handes the beonty sectox. & 12 & 3 & $w$ \\
\hline 90 & $\begin{array}{l}\text { In teims of quantly and quaity, he number of persconnelis atll } \\
\text { lackine. }\end{array}$ & 12 & 3 & $w$ \\
\hline & Overilineage & 195 & 44,75 & \\
\hline
\end{tabular}

The calculation of the number on criterion no.1 is obtained from the total answers of 4 respondents, the total is 29. Then the average value is obtained from the total number of answers divided by the number of respondents so that the average $=29 / 4=$ 7.25. The average value of the respondents' assessment of internal factors, it is known that the calculation of the benchmark value or the average of all internal factors $=4,875$. Obtained from the sum of the average value divided by the number of criterion items $48.75 / 10=4.875$. If the internal factors whose average score is above the benchmark value are grouped as strength, and internal factors whose average score is below the benchmark value are grouped as weaknesses.

From the results of the tabulation of internal factors, it can be seen that the strength factor which 
has the highest average value is Lapetal personnel who have very high motivation/performance, with an average value of 7.25. This, according to the respondents' assessment, is the main strength for Lapetal development. This means that the existence of motivation / good performance from Lapetal personnel becomes the main capital to be able to develop Lapetal. Meanwhile, the weakness factor that gets the lowest average score is the number of Lapetal personnel who are still lacking both in quality and quantity, with an average value of 3 . This, according to respondents, is the biggest weakness in Lapetal development.

\subsection{External Factor Analysis}

After the existing data is collected, and based on document documents, literature review, preliminary interviews with resource persons (Expert), the elements of external factors are obtained as follows:

Table 4. Elements of External Factors

\begin{tabular}{|c|c|}
\hline NO & FACTOR \\
\hline 1 & The existence of the MEF (MinimumEssential Force) program. \\
\hline 2 & $\begin{array}{l}\text { There is a program forrecruting indonesian Nawy solders for special routes in the } \\
\text { eastern region. }\end{array}$ \\
\hline 3 & The evistence of High School Taruna NALA (SMANTAR NALA), East Java. \\
\hline 4 & Public interestio join the indonesian Navyis high. \\
\hline 5 & $\begin{array}{l}\text { There is no maximum supportin the implementation of publications fromrelated } \\
\text { unitsistakeholders within the indonesian Navy. }\end{array}$ \\
\hline
\end{tabular}

Based on the tabulation of external factors, the number of criteria for external factors is obtained, then the classification of opportunity factors (Opportunities) and threat factors (Threats). With the following formula:

$$
\text { Overall average score }=\frac{\text { The average number of each factor }}{\text { Number of factorsfor external criteria }}
$$

Then we get the tabulation of external factors as in the following table:

Table 5. Tabulation of External Factor Elements

\begin{tabular}{|c|c|c|c|c|}
\hline No & FACTOR & Total & Avtsace & ChIEna \\
\hline 1 & 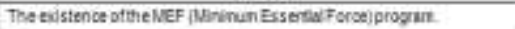 & 30 & 7,5 & $\bar{D}$ \\
\hline 2 & Public niterest to jontes TNI / $/ 2$ is high. & 29 & 725 & 0 \\
\hline 3 & 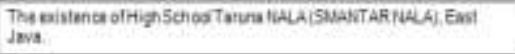 & 26 & 7 & 0 \\
\hline 4 & 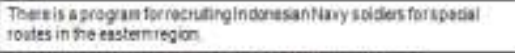 & 27 & 0.75 & D \\
\hline 5 & 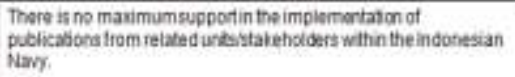 & 24 & 625 & $T$ \\
\hline & Overallaverage & 136 & 39,75 & \\
\hline
\end{tabular}

The calculation of the number on criterion no. 1 is obtained from the total answers of 4 respondents as in the attachment, the total is 30 . Then the average value is obtained from the total number of answers divided by the number of respondents, so that the average $=30 / 4=7.5$. The average value of the respondents' assessment of external factors, it is known that the calculation of the benchmark value or the average of all external factors $=33.75 / 5=6.75$. If external factors whose average value is above the benchmark value are grouped as opportunities, and external factors whose average value is below the benchmark value are classified as threats.
The opportunity factor that has the highest average score is the existence of the MEF (Minimum Essential Force) program, with an average score of 7.5. According to the respondent, this is the greatest opportunity, because it provides an opportunity for Lapetal to develop into a professional human research organization. Meanwhile, the threat factor that has the lowest average value is the absence of maximum support in the implementation of publications from related units/stakeholders within the Indonesian Navy, with an average score of 5.25 . According to respondents, this is the biggest threat in Lapetal development.

\subsection{SWOT data processing}

The following will be weighted internal strategic factors, external strategic factors, and a summary of the results.

\subsubsection{Weighting of Internal Strategy Factors} (IFAS). After determining the strengths and weaknesses of internal factors, then weighting the IFAS can be seen in the following table:

Table 6 . Weighting of IFAS

\begin{tabular}{|c|c|c|c|c|}
\hline FACTOR & TOTaL & wriar & natrus & $\begin{array}{l}\text { Weont : } \\
\text { RATISG }\end{array}$ \\
\hline 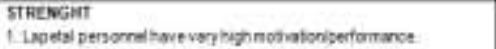 & 28 & 0.447 & $t, \pi$ & 0.26 \\
\hline 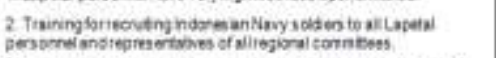 & 28 & 0.1496 & t.75 & 0.25 \\
\hline 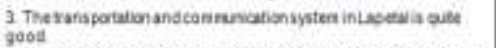 & 27 & $0.13 a 5$ & 225 & 0.31 \\
\hline 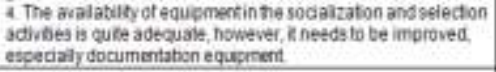 & 26 & $0+13$ & 25 & D. 19 \\
\hline STREVBMT TOTK & & & & 115 \\
\hline WEAKNESS & & & & \\
\hline 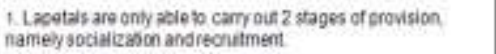 & 17 & $0.04 \pi$ & 2 & 0.17 \\
\hline 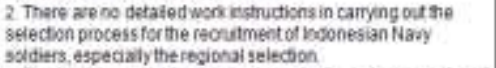 & 15 & 0.070 & 3,6 & 0,27 \\
\hline 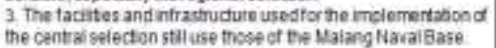 & 16 & 0070 & 3 & 0.23 \\
\hline $\begin{array}{l}\text { 4. There is no special section that handies } \\
\text { scodilcatsonicampaigring }\end{array}$ & 14 & a.ton & 225 & 0,20 \\
\hline 5 no divison hundies the secuntysector. & 12 & 00615 & 3 & 0,18 \\
\hline 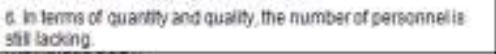 & 12 & 0.0515 & 375 & 0.23 \\
\hline WEWWES & & & & 1,11 \\
\hline TOTE & & & & 2,46 \\
\hline
\end{tabular}

The calculation of the amount for the strength factor on no. 1 is obtained from the total answers of 4 respondents, namely 29. Then the total number of answers to 4 respondents from the strength and weakness factors is 195 . The calculation of the weight of the strength factor on no. 1 is obtained from the total answers of 4 respondents divided by the total number answer, namely as follows: weight $=29 / 195=0.1487$.

Based on the IFAS matrix table above, it can be seen that the weighting of the internal factor rating, where the weighting is done to know how much the factors influence or have an impact on the strategic factor itself. The weighting of the strategic factors in the table is obtained from the total strength score of 1,15 and the total weakness score of 1,31 so that the overall total of internal factors is 2.46 . The purpose of this rating is to provide a scale ranging from 4 to 1 based on these factors for Lapetal development. The overall score shows how Lapetal development reacts to its internal strategy factors. 
3.5.2. Weighting of External Strategy Factors (EFAS). After determining the strengths and weaknesses of internal factors, then weighting the IFAS can be seen in the following table:

Table 7. Weighting of EFAS

\begin{tabular}{|c|c|c|c|c|}
\hline FACTOR & $\begin{array}{c}\text { TOTA } \\
\mathrm{L}\end{array}$ & $\begin{array}{c}\text { WoGal } \\
T\end{array}$ & $\begin{array}{c}\text { RATW } \\
G\end{array}$ & $\begin{array}{l}\text { WEicarT } \\
\text { nariwg }\end{array}$ \\
\hline OPPORTUMITY & & & & \\
\hline 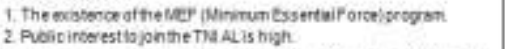 & $\frac{x 0}{29}$ & $\begin{array}{l}0.2222 \\
0.2148\end{array}$ & 3,26 & $\begin{array}{l}\text { Q.72 } \\
0.21\end{array}$ \\
\hline 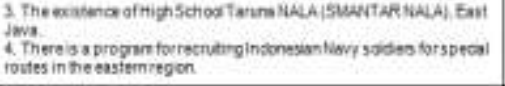 & $\begin{array}{l}2 x \\
27\end{array}$ & $\begin{array}{r}0.0074 \\
0.2\end{array}$ & $\begin{array}{r}2.76 \\
3\end{array}$ & $\begin{array}{r}0.57 \\
0.6\end{array}$ \\
\hline OPAORTUUITVTOTAL & & & & 27 \\
\hline 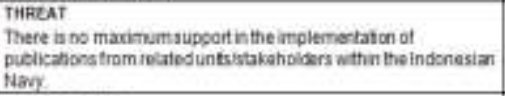 & 21 & 0.1566 & 5.26 & 0.9 \\
\hline TPREAT TOTAL & & & & 0.51 \\
\hline TOTAL & & & & 3,11 \\
\hline
\end{tabular}

The calculation of the number for the opportunity factor on no.1 is obtained from the total answers of 4 respondents, namely 30 . Then the total number of answers to 4 respondents from the opportunity and threat factors is 135 . The calculation of the weight of the opportunity factor on no.1 is obtained from the total answers of 4 respondents divided by the total number answer, namely as follows: weight $=30 / 135=0.2222$. Based on the table above, it shows that the weighting of the external strategy factor rating for Lapetal development, where the weighting is done to know how much the factors influence or have an impact on the strategy factor itself. The weighting of the strategic factors in the table is obtained from the total opportunity score of 2.7 and the total threat score of 0.51 so that the overall total of external factors is 3.21 . The purpose of this rating is to provide a scale from 4 to 1 based on these factors for Lapetal Development. The overall total score shows how Lapetal development factors against external factors.

3.5.3. Recapitulation of the calculation of strengths, weaknesses, opportunities, and threats.

Based on the results of calculations that have been carried out through the SWOT analysis, the final value of internal factors, namely strengths and weaknesses, as well as external factors, namely opportunities and threats, and the weighting results of the SWOT matrix, can be briefly seen in the following table:

Table 8. Comparison of IFAS and EFAS

\begin{tabular}{|c|r|r|}
\hline IFAS & $S=1,15$ & $W=1,31$ \\
\hline$O=2,7$ & 3,85 & 4,01 \\
\hline$T=0,51$ & 1,66 & 1,82 \\
\hline
\end{tabular}

The results of the IFAS-EFAS interaction resulted in an alternative strategy that received the highest weight, namely Weaknesses - Opportunities (WO), which can be translated as a strategy that takes advantage of opportunities by maximizing the weaknesses they have. This condition is favorable for Lapetal because, from the external factor side, the existing opportunities are much greater than the threats in the framework of Lapetal development. The strategy formulation is obtained through a combination of elemental factors, S, W, O, and T, resulting in several strategic combinations as follows.

The WO strategy has the highest weight (4.01) so it is the first alternative in the Lapetal development strategy. The WO strategy consists of 6 (six) substrategies, including:

a. To study the organizational structure of Lapetal to be proposed to the leadership element in the framework of developing (organizational validation) of Lapetal, so that the special parts that have not been handled can be included in the larger organizational structure, including; Socialization/campaign, security, Taruna Nala High School, etc.

b. Making detailed work instructions regarding the implementation of the selection of candidates for the recruitment of Indonesian Navy soldiers, both at the regional and central levels.

c. Make suggestions to the leadership regarding the improvement/transfer of rights to use existing facilities and infrastructure in the Malang Navy Base. d. With the increase in the size of the Lapetal organizational structure, it is necessary to increase the number of personnel, this is due to the increasing number of duties and responsibilities that are carried out by Lapetal.

e. Conducting training to improve the quality of Lapetal personnel, including; computer training, training on checking the completeness and validity of documents, training on medical examinations, physical testing training, and other training regarding the implementation of recruiting Indonesian Navy soldiers.

f. Coordinate and cooperate with relevant stakeholders within the Indonesian Navy to carry out socialization and publication to the maximum regarding the recruitment of prospective Indonesian Navy soldiers to increase public knowledge and interest in the Indonesian Navy.

\section{CONCLUSION}

This research has several stages to achieve the expected goals. Starting from the problem identification stage and data collection taken from journals, books, field studies, and questionnaires to selected experts. The next stage is to continue with the identification and formulation of strategies. In this study, the SWOT analysis method was used to identify and formulate several Lapetal development strategies. The SWOT analysis method used in this development strategy integrates with the existing conditions of the Lapetal, the corridor of the MEF military strategy area, the Navy strategy and government policies on the World Maritime Axis. This stage consists of (1) determining the external opportunity factors of Lapetal; (2) Determining threat factors; (3) Determining the strength factors; (4) Determining the weakness factors; (5) Determining the Strategy I SO (Strength-Opportunity); (6) Determining the II WO (Weakness-Opportunity) 
Strategy; (7) Strategy III ST (strength-threat); (8) Determine the WT strategy IV (weakness-threat).

In the formulation of the Lapetal development strategy, (four) alternative strategies were obtained, namely the SO strategy, the WO strategy, the ST strategy, the WT strategy. SO strategy consists of 7 (seven) strategic steps. ST strategy consists of 5 (five) strategy steps. The WO strategy consists of 6 (six) strategy steps and the WT strategy consists of 4 (four) strategic steps. In the next step, all the strategic steps will be determined the priority weight so that the main strategy chosen can be found. Based on the results of the weight calculation, it is known that the WO Strategy has the highest weight (4.01) so that it becomes the first alternative in the Lapetal development strategy. The WO strategy consists of 6 (six) sub-strategies.

\section{ACKNOWLEDGEMENT}

The authors greatly acknowledge the support from Naval Technology College, STTAL Surabaya Indonesia for providing the necessary resources to carry out this research work. The authors are also grateful to the anonymous reviewers and journal editorial board for their many insightful comments, which have significantly improved this article.

\section{REFERENCES}

Collins- Kreiner, N. \&. (2007). Evaluating tourism potential: A SWOT analysis of the Western Negev. Israel, Tourism. 55, 51 - 63.

Harky, Y. F. (2018). The Significance of Recruitment and Selection on Organizational Performance: The Case of Private owned Organizations in Erbil, North of Iraq. International Journal of Contemporary Research and Review, 2039320401.

Hill, T. \&. (1997). SWOT Planning (30 ed.).

Istiqomah, A. (2017). Strategi pengembangan Sumber Daya Manusia sebagai upaya untuk meningkatkan kinerja aparatur desa dengan menggunakan analisis SWOT. Jurnal Universitas Negeri.

Lapetal. (2018). Materi Hand Book Lapetal. Malang: Lapetal.

Mabes TNI. (2014). Peraturan Panglima TNI Nomor 30 tahun 2014 tentang Penyediaan Prajurit Sukarela Tentara Nasional Indonesia. Jakarta: Mabes TNI.

Mabes TNI AL. (2001). Surat Keputusan Kepala Staf Angkatan Laut (Kasal) Nomor Kep/05/II/2001 tanggal 8 Februari 2001 tentang Organisasi dan Prosedur Dinas Administrasi Personel TNI $A L$. Jakarta: Mabes TNI AL.

Mabes TNI AL. (2013). Surat Keputusan Kepala Staf Angkatan Laut Nomor Kep/1178/IX/2013 Tanggal 12 September 2013 tentang Daftar Susunan Personel Lapetal. Jakarta: Mabes TNI AL.

Mashudi, A. (2019). STTAL Development Strategy to Produce Human Resources that Acknowledge Technology Facing The Industrial Revolution Era 4.0. International Journal of ASRO STTAL, 27-33.

Wasike, C. B. (2010). Factors that influence the efficiency of beef and dairy cattle recording system in Kenya: A SWOT - AHP analysis. . Trop Anim Health Prod.

Wheelen, T. L. (2012). Strategic Management and Business Policy: Toward Global Sustainability (13th ed.) (13th ed.). New Jersey: Pearson Education.

Yuksel, I. \&. (2007). Using the Analytic Network Process (ANP) in a SWOT Analysis - A Case Study for a Textile Firm. 